\title{
Isolation and Characterization of Exopectinase from Bacillus licheniformis FMB9 Isolated from Agricultural Soil
}

\author{
Fatimah Alqahtani ${ }^{1,2}$, Magda Aly ${ }^{1,3^{*}}$, Fardos Bokhari', Baher Ali El-Nogoumy³, Wafa Alshehri ${ }^{4}$
}

'Department of Biology, College of Science, King Abdullaziz University, Jeddah, Saudi Arabia.

2Department of Biology, College of Science and Arts in Tathleet, University of Bisha, Bisha, Saudi Arabia.

3Botany and Microbiology Department, Faculty of Science, Kafrelsheikh University, Egypt.

${ }^{4}$ Department of Biology, College of Science, University of Jeddah, Jeddah, Saudi Arabia.

*Correspondence to: Magda Aly (E-mail: magdammali@hotmail.com)

(Submitted: 02 July 2021 - Revised version received: 23 July 2021 - Accepted: 12 August 2021 - Published online: 26 October 2021)

\begin{abstract}
Objectives: This study aimed to isolate and identify potential pectinase producing bacterium as well as optimization of its various parameters for maximum enzyme production.

Methods: A total of forty-three bacterial isolates were obtained from agriculture soil in Jeddah city using standard plate count method. Primary screening was done by hydrolysis of pectin on agar plate and measuring the clear zone after adding iodine-potassium iodide solution. Pectinase activity was determined by measuring the increase in reducing sugar formed by the enzymatic hydrolysis of pectin.

Results: Among the bacterial isolates, the isolate FMB9 exhibited higher pectinase activity in broth medium and was selected for further studies. The selected bacterial isolate FMB9 was identified as Bacillus licheniformis FMB9 with similarity level 97\% to B. licheniformis AS10. The isolate was found to produce maximum pectinase at $37^{\circ} \mathrm{C}$ with $\mathrm{pH} 7$ upon incubation for 72 hours, while cultured in production medium containing citrus pectin and yeast extract as carbon and nitrogen sources, respectively. The enzyme was purified using column chromatography and was characterized. It showed maximum activity at $45^{\circ} \mathrm{C}$. Bacillus licheniformis pictinase was affected by pH values and optimum activity was at pH 5. The molecular weight was also determined and compared with other pectinases.

Conclusion: Pectinase produced from bacteria can be purified and used in many technological applications in food and medicine.

Keywords: Pectin; pectinase; Bacillus licheniformis; enzyme activity; 16s rRNA
\end{abstract}

\section{Introduction}

Pectin is an important component of the middle lamella and primary cell wall of higher plants. Pectins are high molecular weight acidic heteropolysaccharide primarily made up of a (1-4) linked d-galacturonic acid residues. ${ }^{1}$ Degradation of pectin is difficult, and pectinases enzyme can help in the degradation of pectin. ${ }^{2}$ Pectinases consist of a unique group of enzymes that catalyze the degradation of pectic polymers, they belong to the polysaccharidase family, also known as pectolitic or pectic enzymes, which contribute to the breakdown of pectins from various plants. In the current biotechnological period, pectinase is one of the increasingly used enzymes. ${ }^{3}$ Pectinases, used since 1930, make up a significant part of industrial enzymes. There are different sources of pectinolytic enzymes; including bacteria, fungi, plant, ${ }^{4}$ and no evidence was found in animal. ${ }^{5}$ Microbial enzymes are routinely used in many environmentally friendly and economic industrial sectors.

Pectinases are enzymes which are widely distributed in microbes that are present in pectin enriched sites. The agroindustrial residues can be utilized in the industrial scale for low-cost and efficient pectinase production in an eco-friendly approach. ${ }^{6}$

Most pectin-degrading microorganisms are associated with raw agricultural products and with soil. Up to $10 \%$ of the microorganisms in soil have been shown to be pectinolytic. ${ }^{78}$ These include, but are not limited to, bacteria in the genera Pantoea, Achromobacter, Aeromonas, Arthrobacter, Agrobacterium, Enterobacter, Bacillus, Clostridium, Erwinia, Flavobacterium, Pseudomonas, Xanthomonas. ${ }^{9-11}$ And many yeasts, molds, protozoa and nematodes. ${ }^{12}$ Also pectolytic activity was found in a strain of Leuconostoc mesenteroides. ${ }^{13}$
Bacillus is one of the large genera of bacterial strains. It is a rod shaped, endospore bearing bacteria and belong to the family Firmicutes. The genus Bacillus covered a great diversity of strains and some of them are strictly aerobic, while others are facultative anaerobic. The Bacillus especially B. licheniform is capable of growing on a large diversity of nutrient sources because of synthesizing and secreting different hydrolytic enzymes and this quality makes the B. licheniform is an industrially important microorganism. ${ }^{14}$

In the current study, different bacterial strains were isolated from agriculture soil and screened for pectinase production. Finally, maximum pectinase producing bacterial strain was identified using conventional and molecular techniques.

\section{Materials and Methods}

\subsection{Isolation of Bacteria}

Several bacterial strains were isolated from soil samples collected from agriculture soil in Jeddah city. Isolation of bacteria was done by serial dilution plate method and incubated at $37^{\circ} \mathrm{C}$ for $24 \mathrm{hrs}$. The isolated colonies were selected to obtain pure bacterial cultures.

\subsection{Screening of Pectin Producing Bacteria}

Screening was performed to detect the presence of bacteria that degrades pectin. Pectin agar medium was prepared with $(\mathrm{g} / \mathrm{L})$ : $\mathrm{NaNO}_{3} 1.0, \mathrm{KCl} 1.0, \mathrm{~K}_{2} \mathrm{HPO}_{4} 1.0, \mathrm{MgSO}_{4} 0.5$, yeast extract 0.5, citrus pectin 10 and agar 20 with $\mathrm{pH}$ adjusted to 7.0 (Kumar et al., 2012).Pure culture was inoculated by puncture in the medium and incubated for $48 \mathrm{hrs}$ at $37^{\circ} \mathrm{C}$. After incubation, iodine-potassium iodide solution was added to detect the clearance zone. ${ }^{15}$ 


\subsection{Quantitative Screening of Bacterial Strains for Pectinase Production}

The bacterial strains showing clear zone of hydrolysis on pectin agar medium were screened for pectinase production using pectin broth medium. The pure cultures were inoculated and incubated at $37^{\circ} \mathrm{C}$ for $24 \mathrm{~h}$. After incubation, biomass was separated by centrifugation at $10,000 \mathrm{rpm}$ for $15 \mathrm{~min}$. The supernatant was used to evaluate pectinase activity. ${ }^{16}$

\subsection{Enzyme Assay}

Pectinase activity was measured by the estimation of the amount of galacturonicacids through the DNS method (Miller, 1959) ${ }^{17}$ using $1.0 \%$ citrus pectin as a substrate and mono-Dgalacturonic acid as a standard. One unit of pectinase was defined as the "amount of enzyme required to generate 1 mole of galacturonic acid under standard assay conditions".

The enzyme activity $(\mathrm{U} / \mathrm{mL})$ was calculated according to equation:

Enzyme activity $(\mathrm{U} / \mathrm{mL})=\frac{(\mu \text { galacturonic acid released } \times V)}{V \times 194.1 \times t}$

where $v$ is the enzyme broth volume used in the assay, 194.1 is the molecular weight of galacturonic acid, and $t$ is the reaction time in min. One unit $(\mathrm{U})$ is equivalent to $1 \mu \mathrm{mol}$ product released per min.

Relative activity of the enzyme was calculated as the percentage by using the following formula: ${ }^{18}$

Relative activity $=\frac{\text { Activity of the sample } \times 100}{\text { Maximum activity of the sample }}$

\subsection{Identification of Bacterial Strain}

Morphological characteristics, biochemical characterization of the selected bacterial strain were studies for identification. ${ }^{19}$ Molecular characterization 16S rDNA sequence analysis was performed for molecular based identification of selected isolate. The genomic DNA was extracted using the method reported by Chen and Kuo (1993). ${ }^{20}$

\subsection{Optimization of Cultural Conditions for Pectinase Production by Bacillus licheniformis FMB9}

The bacterial strain that showing high pectinolytic activity was selected. The effects of temperature, $\mathrm{pH}$ and incubation period on production of pectinase were studied for maximum pectinase production.

The bacterial isolate was subjected to different temperatures $\left(25,30,37,40\right.$ and $\left.45^{\circ} \mathrm{C}\right)$ for $72 \mathrm{~h}$ then the enzyme activity was measured. After selection the best optimum temperature of pectinase production, the effect of $\mathrm{pH}$ value on pectinase production of the selected bacterial isolate were studded. The medium was prepared with different $\mathrm{pH}$ values ( $\mathrm{pH}$ 5.0, 6.0, 7.0, 8.0 and 9 ) and incubated $72 \mathrm{~h}$ with agitation at $120 \mathrm{rpm}$ at $37^{\circ} \mathrm{C}$. After growth period, pectinase activity was measured. After selection the best $\mathrm{pH}$ of the medium, the effect of different incubation period ( $24 \mathrm{~h}, 48 \mathrm{~h}, 72 \mathrm{~h}, 96$, and $120 \mathrm{~h}$ ) was determined. After incubation the enzyme assay was measured.

\subsection{Purification and Enzymatic Optimization}

Production of pectinase by Bacillus licheniformis was carried out for $72 \mathrm{hrs}$ and the enzyme was precipitated by $80 \%$
Ammonium sulfate in the refrigerator at $4^{\circ} \mathrm{C}$, the precipitate was collected and centrifuged at the same temperature and the obtained crude enzyme was dialyzed at $4^{\circ} \mathrm{C}$ for two days with citrate buffer of $\mathrm{pH} 5$. The obtained protein was frozen at $-200^{\circ} \mathrm{C}$ and lyophilized in a lyophilizer. The enzyme was purified using sephadex G-100 and DEAE-cellulose columns chromatography where the enzyme was directly applied to the agarose column $(1 \times 30 \mathrm{~cm}$. $)$ and elution was carried out by liner gradient of $\mathrm{NaCl}(0.1-0.6 \mathrm{M})$. Many fractions (60), each one bout $5 \mathrm{ml}$, were collected and enzyme activity and protein content $\left(\mathrm{A}_{280}\right)$ were determined. Total protein was determined by the method of Lowery et al. $(1951)^{21}$ by using serum albumin as a standard.

\subsection{Characterization of the Purified Enzyme}

The purified enzyme was characterized at different $\mathrm{pH}$ (5-9), temperature $\left(20-60^{\circ} \mathrm{C}\right)$ and substrate and enzyme concentrations. The molecular weight of pectinase that was purified was determined using a vertical gel electrophoresis including 12\% separating and 5\% stacking gel and low molecular weight protein was used as standard (Laemmli, 1970). ${ }^{22}$ Protein bands were examined after staining with Coomassie Brilliant Blue R-250.

\subsection{Statistical Analysis}

The data for all experiments have been calculated from three replications, with the values presented as the mean $\pm \mathrm{SE}$ standard error).

\section{Results and Discussion}

Pectinolytic enzyme can be derived from different sources. ${ }^{23}$ However, pectinase producing microorganisms have due advantage over other sources because they can be subjected to genetic and environmental manipulations to increase yield. ${ }^{24}$ It has been reported that most Bacillus sp, enhances the production of pectinase. ${ }^{25}$

Forty-three bacterial strains were isolated from agriculture soil in Jeddah city on nutrient agar. The pectinolytic activity was detected by visualizing a clear zone around the colony using potassium-iodide flooding method. ${ }^{17}$ Among these isolates only twenty-five isolates showed pectinolytic activity on pectin agar medium (Table 1). The isolate FMB9 (Figures 1, 2) which was Gram positive bacterium, isolated from soil on nutrient agar medium demonstrated the largest hydrolysis zone around its colony, meaning the highest pectinase activity, compared to the other strains.

To identify the selected isolate FMB9, both traditional microbiological methods and modern molecular technologies were considered. On the basis of observed morphological, cultural, and biochemical characteristics, the colony of selected bacterial isolate FMB9 was large and the margin was undulate and had white creamy color. It cells were Gram positive, motile and producing endospore. This isolate had shown positive test for catalase, oxidase, starch hydrolysis, protease and can able to ferment glucose and sucrose whereas, negative for urease, citrate utilization, gelatin liquefaction and DNAase. The results obtained were compared with identification flowchart of Bergey's Manual. ${ }^{19}$ The characteristics showed by this organism were fairly similar to Bacillus licheniformis. The details of biochemical characteristics of pectinase producing strain are given in Table 2. The phylogenetic tree generated using $16 \mathrm{~S}$ 


\begin{tabular}{|c|c|c|}
\hline Bacteria isolates & $\begin{array}{l}\text { Diameter of clear } \\
\text { zone }(\mathrm{mm})\end{array}$ & $\begin{array}{l}\text { Pectinase activity } \\
(\mathrm{U} / \mathrm{ml})\end{array}$ \\
\hline FMB 1 & $19.0 \pm 2.3$ & 1.191 \\
\hline FMB 2 & $10.3 \pm 2.3$ & $1.0 \pm 0.3$ \\
\hline FMB 3 & $33.0 \pm 2.3$ & $0.5 \pm 0.3$ \\
\hline FMB 4 & $14.3 \pm 2.3$ & 0.611 \\
\hline FMB 5 & $28.6 \pm 2.3$ & $0.6 \pm 0.3$ \\
\hline FMB 6 & $27.9 \pm 2.3$ & $1.2 \pm 0.4$ \\
\hline FMB 7 & $13.3 \pm 2.3$ & $0.4 \pm 0.0$ \\
\hline FMB 8 & $13.3 \pm 2.0$ & $0.6 \pm 0.3$ \\
\hline FMB 9 & $33.6 \pm 2.8$ & $1.4 \pm 0.5$ \\
\hline FMB 10 & $30.3 \pm 2.0$ & $1.2 \pm 0.4$ \\
\hline FMB 11 & $30.9 \pm 2.0$ & $0.7 \pm 0.3$ \\
\hline FMB 12 & $28.3 \pm 3.3$ & $0.7 \pm 0.1$ \\
\hline FMB 13 & $30.0 \pm 3.3$ & $0.7 \pm 0.3$ \\
\hline FMB 14 & $17.8 \pm 2.4$ & $0.8 \pm 0.2$ \\
\hline FMB 15 & $32.1 \pm 2.9$ & $0.6 \pm 0.1$ \\
\hline FMB 16 & $17.1 \pm 2.7$ & $0.5 \pm 0.1$ \\
\hline FMB 17 & $24.6 \pm 2.8$ & $0.7 \pm 0.3$ \\
\hline FMB 18 & $30.1 \pm 2.9$ & $0.7 \pm 0.1$ \\
\hline FMB 19 & $28.3 \pm 2.0$ & $0.6 \pm 0.1$ \\
\hline FMB 20 & $15.3 \pm 2.1$ & $0.5 \pm 0.2$ \\
\hline FMB 21 & $24.3 \pm 2.0$ & $0.7 \pm 0.3$ \\
\hline FMB 22 & $29.3 \pm 2.3$ & $0.9 \pm 0.3$ \\
\hline FMB 23 & $23.0 \pm 1.4$ & $0.6 \pm 0.2$ \\
\hline FMB 24 & $24.6 \pm 5.1$ & $0.7 \pm 0.0$ \\
\hline FMB 25 & $26.3 \pm 2.5$ & $0.5 \pm 0.1$ \\
\hline
\end{tabular}

Table 2. Morphological, physiological and biochemical characteristics of maximum pectinase producing bacterial strain

\begin{tabular}{lc}
\hline Characteristics & Results \\
\hline Temperature range & $20-45^{\circ} \mathrm{C}$ \\
Optimum temperature & $37^{\circ} \mathrm{C}$ \\
$\mathrm{pH}$ range & $5.5-10.0$ \\
Optimal pH & $6.5-7.5$ \\
Catalase & + \\
Oxidase & + \\
Urease & - \\
Protease & + \\
DNAase & - \\
Hydrolysis of starch & + \\
Gelatine liquefaction & - \\
Citrate utilization & - \\
\hline
\end{tabular}
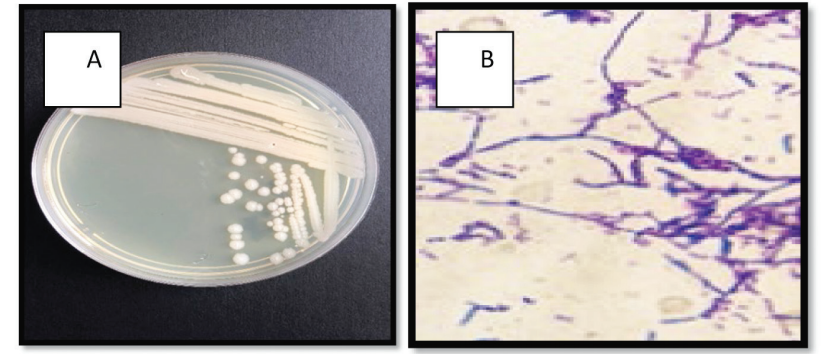

Fig. 1 Isolate FMB9, A: On nutrient agar, B: Under light microscope after Gram staining.
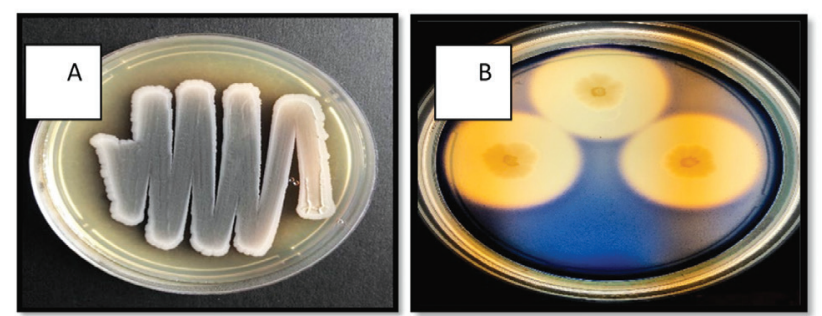

Fig. 2 A: Isolate FMB9 growth on pectin agar medium, B: Qualitative screening of the isolate FMB9 for pectinase on pectin agar medium.

rDNA gene sequences of the bacterial isolate showed that the bacterium has the highest homology (99\%) with Bacillus licheniformis (GenBank Accession Number KJ729823.1) and designated as Bacillus licheniformis AS10. Figure 3 signifies the phylogenetic tree of the isolate FMB9 with the selected best homologous known bacterial strains.

For the production of pectinase in optimum cultural condition the bacteria strain was grown on pectin broth media. Factors such as temperature, $\mathrm{pH}$ and incubation periods were varied to analyze the optimum enzyme production by the bacteria strain.

Enzyme production went up with the increase of temperature up to $37^{\circ} \mathrm{C}$ and then declined (Figure 4). The maximum production which occurred at this temperature was $2.77 \mathrm{U} / \mathrm{ml}$. This dramatically reduced to nearly $16.6 \%$ at $50^{\circ} \mathrm{C}$. In the previous study of Aaisha and Barate (2016), ${ }^{26}$ the highest pectinase production was observed from some Bacillus species at $37^{\circ} \mathrm{C}$ which is similar to our current study.

Enzyme activity also depends on the $\mathrm{pH}$ of the reaction mixture. Figure 4 depicts the effect of different pHs on the production of pectinase by Bacillus licheniformis. Maximum production $(2.64 \mathrm{U} / \mathrm{ml})$ was recorded at $\mathrm{pH} 7$ (Figure 5). This finding is in accordance with other workers who reported that most of the Bacillus sp. that produce high amount of pectinase between $\mathrm{pH} 7$ and 8 (Oumer and Abate, 2017). ${ }^{27}$ At highly acidic and alkaline $\mathrm{pH}$, enzyme production decreased by almost $61.37 \%$ and $51.5 \%$, respectively.

An attempt was made to determine the most favorable incubation period for enzyme production by the selected isolate and the highest enzyme production $(2.852 \mathrm{U} / \mathrm{ml})$ was recorded after 72 hours of incubation (Figure 6). The enzyme production gradually decreased to $0.361 \mathrm{U} / \mathrm{ml}$ at 120 hours of incubation which is almost $51 \%$ less than that of maximum. This might be due to the accumulation of waste products at prolonged incubation time with limited nutrient sources which consequently suppressed the growth of microorganism. According to Nawawi et al. (2017) ${ }^{28}$ maximum pectinase 
Tree scale: 0.01

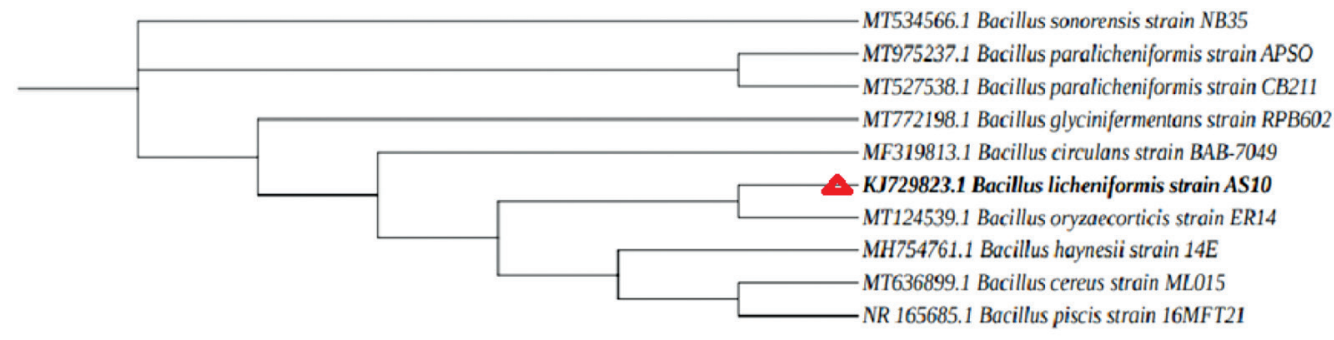

Fig. 3 Phylogenetic tree of the identified bacterial isolate FMB9 based on the 16S rDNA sequences. The GenBank accession number is given in parentheses for each organism.

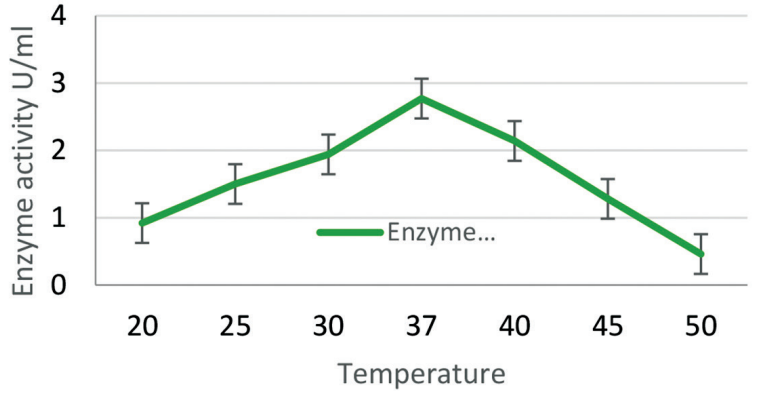

Fig. 4 Effect of different temperature on pectinase production by Bacillus licheniformis FMB9.

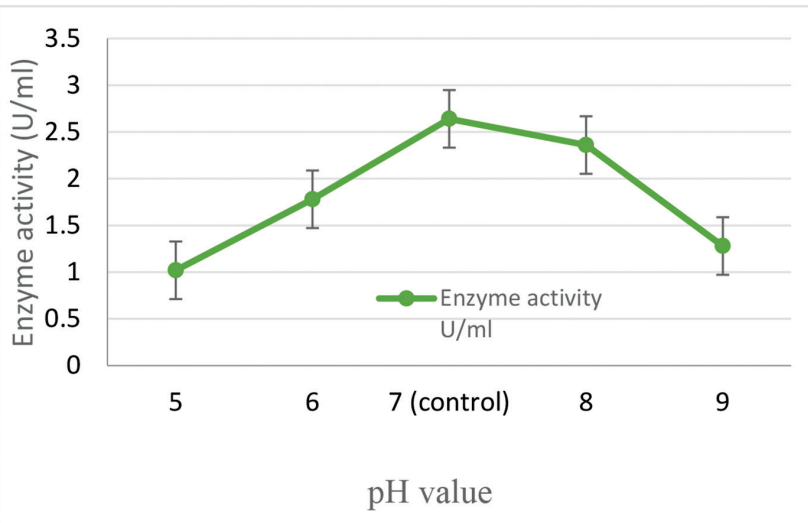

Fig. 5 Effect of different pH on pectinase production by Bacillus licheniformis FMB9.

production was determined from the Bacillus subtilis ADI1 after 72 hours of incubation which well agreed with our findings. On the other hand, this study is disagreeing with other study which reported that Bacillus licheniformis strain DY2 had maximum pectinase production after $44 \mathrm{hrs}^{29}$

The elution profiles of the crude enzyme of isolate FMB9 after using Sephadex G-100 and DEAE-cellulose columns chromatography are shown in Figures 7 and 8, respectively. For each column chromatography, the fractions with the

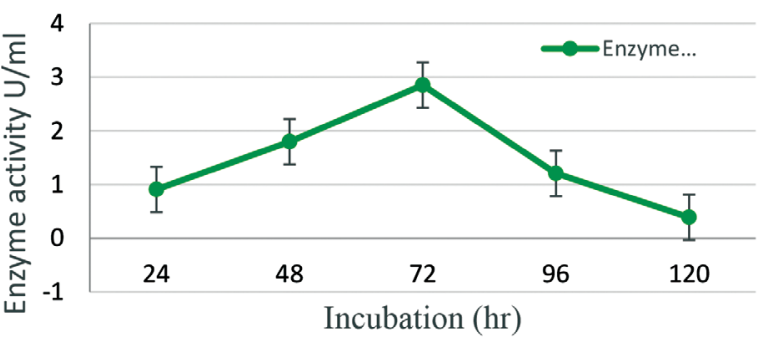

Fig. 6 Effect of different incubation period on pectinase production by Bacillus licheniformis FMB9.

highest pectinase activity have been collected, concentrated by lyophilization and the enzyme activity was determined. Molecular weight of the pure enzyme, detected using SDSPAGE analysis, was $\sim 43 \mathrm{kDa}$ (Figure 9). According to the SDSPAGE analysis, two extracellular pectinase of 60 and $64 \mathrm{kDa}$ were obtained from Bacillus subtilis by Takc1 and Turkmen (2016)..$^{30}$ Molecular weights of the partial purified pectinase from various bacteria species were determined as follows: 37 $\mathrm{kDa}$ for Paenibacillus xylanolyticus and Bacillus sp. MFW7, 11,32 $89 \mathrm{kDa}$ for Bacillus cereus NRC20, ${ }^{33} 31 \mathrm{kDa}$ for Streptomyces sp. GHBA10, ${ }^{34} 106 \mathrm{kDa}$ for Bacillus sp. DT7 ${ }^{35}$ and $66 \mathrm{kDa}$ for Bacillus sp. MBRL576. ${ }^{36}$ Higher molecular weight enzymes were isolated from Kluyveromyces marxianus ${ }^{37}$ while an average molecular weight of $38-65 \mathrm{kDa}$, the enzymes (for both exo- and endopolygalacturonases) are separated from various microbial sources. ${ }^{38}$ The purified enzyme showed maximum activity at $45^{\circ} \mathrm{C}$ and $\mathrm{pH} 5$ (Tables 3,4 ) in addition to $0.7 \mathrm{mM}$ of the substrate (Figure 10). It was found that increase enzyme and substrate concentrations enhanced enzyme activity. In the presence of excess substrate, increasing enzyme concentrations increased the enzyme activity (Figure 11). Addition of $\mathrm{Mg}^{2+}, \mathrm{K}^{+}, \mathrm{Zn}^{2+}$ and $\mathrm{Ca}^{2+}$ ions significantly increased the enzyme activity while $\mathrm{Na}^{+}, \mathrm{Fe}^{2+}$ and $\mathrm{Cu}^{2+}$ in addition to EDTA decreased the activity (Table 5).

Pectinases or pectinolytic enzymes that hydrolyze pectic substances are produced by living cells in the presence of 


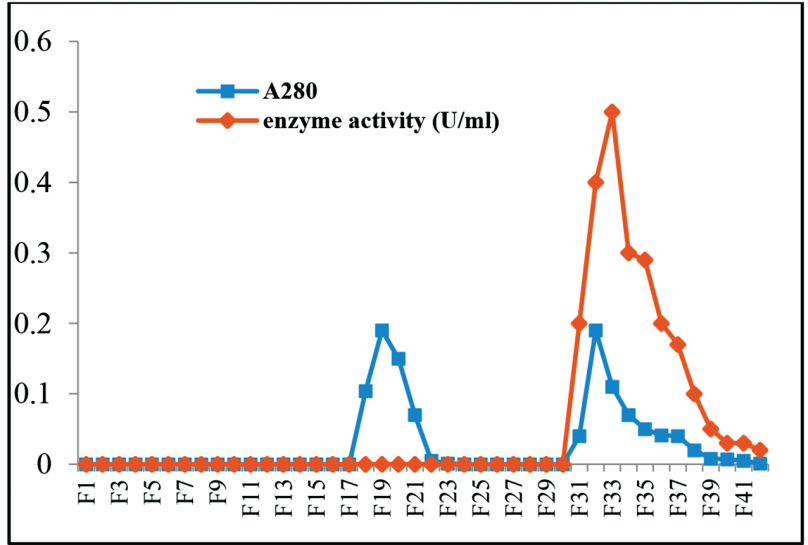

Fig. 7 Elution profile of pectinase after sephadex G-100 chromatography.

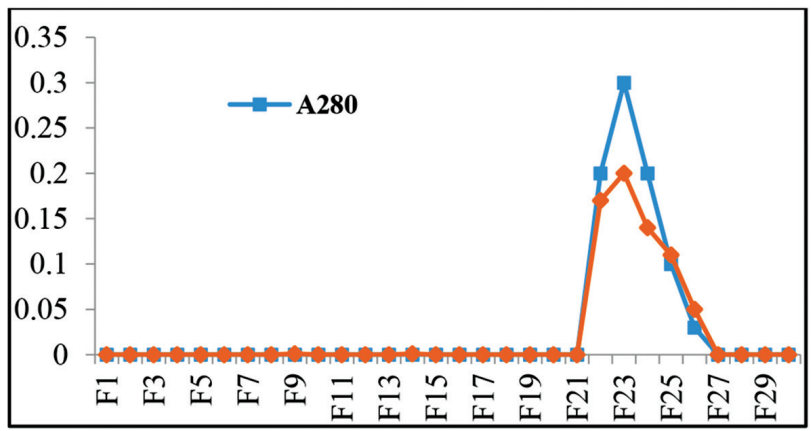

Fig. 8 Elution profile of peptidase after DEAE-cellulose chromatography.

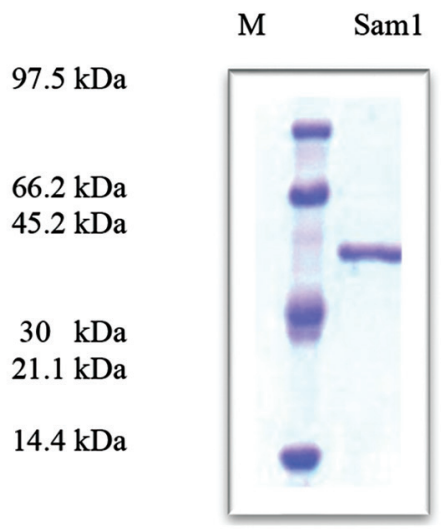

Fig. 9 The molecular weight of purified pectinase isolated from isolate FMB9 by SDS-PAGE, M: protein standards employed were phosphorylase (97 kDa), albumin (66 kDa), ovalbumin (45 kDa), carbonic anhydrase (30 kDa), soybean trypsin inhibitor (20.1 kDa), and a-lactalbumin (14.4 kDa), lane 2: Purified pectinase.

pectin. They are classified into three groups, protopectinases, esterase, and depolymerases. ${ }^{39}$ Protopectinases break down protopectin to soluble pectin, Esterase which removes methoxyl and acetyl esters from pectin forming polygalacturonic acid and Depolymerases which breakdown $a-(1 \rightarrow 4)$-glycosidic bonds in units either by hydrolysis or by trans elimination. ${ }^{38,40}$ Most of the polygalacturonase enzymes stimulate the rate of hydrolysis at an ideal $\mathrm{pH}$ ranging from 3.5 to 5.5 with a suitable temperature that ranges from 30 to $50^{\circ} \mathrm{C}$. Several findings relating to various biochemical properties like molecular

\begin{tabular}{lcc}
\multicolumn{3}{l}{$\begin{array}{l}\text { Table 3. Effect of different temperature on Bacillus } \\
\text { licheniformis pectinase activity }\end{array}$} \\
\begin{tabular}{ccc}
\hline Incubation \\
temperature ( $\left.^{\circ} \mathbf{C}\right)$
\end{tabular} & $\begin{array}{c}\text { Enzyme activity } \\
\mathbf{U} / \mathbf{m l}\end{array}$ & Relative activity (\%) \\
\hline 20 & $0.99^{*} \pm 0.12$ & 47.8 \\
25 & $1.10 \pm 0.11$ & 53.1 \\
30 & $1.80 \pm 0.25$ & 86.9 \\
$37($ control) & $2.07 \pm 0.12$ & 100.0 \\
40 & $2.14 \pm-0.28$ & 103.3 \\
45 & $2.28 \pm 0.16$ & 110.1 \\
50 & $2.00 \pm 0.15$ & 96.6 \\
55 & $1.09 \pm 0.22$ & 52.6 \\
60 & $0.40 \pm 0.21$ & 19.4 \\
\hline
\end{tabular}

*Values are mean \pm SD of 3 replicates.

\begin{tabular}{ccc}
\hline $\begin{array}{l}\text { Table 4. Effect of different pH on pectinase activity from } \\
\text { Bacillus licheniformis }\end{array}$ \\
\hline pH value & Enzyme activity U/ml & Relative activity (\%) \\
\hline 5 & $2.69 \pm 0.09$ & 119.0 \\
6 & $2.50 \pm 0.12$ & 110.6 \\
7 (control) & $2.26 \pm 0.13$ & 100.0 \\
8 & $2.20 \pm 0.11$ & 97.3 \\
8.5 & $2.11 \pm 0.22$ & 93.3 \\
9 & $1.33 \pm 0.05$ & 58.8 \\
\hline
\end{tabular}

Values are mean \pm SD of 3 replicates.

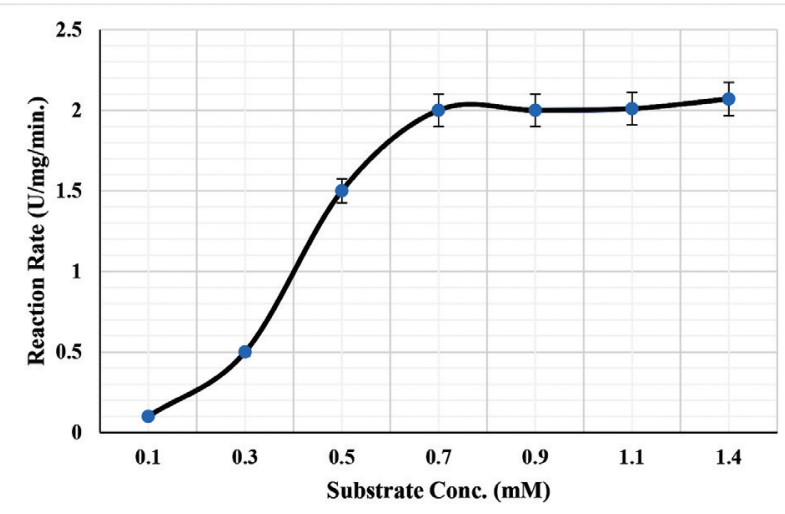

Fig. 10 Effect of different substrate concentration on pectiinase activity.

weight, $\mathrm{pH}$, temperature, isoenzyme, isoelectric point, etc. are well-reported with respect to endopolygalacturonase in various bacterial and fungal species as compared to exopolygalacturonase and rhamnopolygalacturonase. As reported, almost all endopolygalacturonase as well as exopolygalacturonase enzymes are synthesized in acidic environmental conditions, whereas, some exopolygalacturonases are produced at high basic conditions (about $\mathrm{pH} 11.0$ ) and by particular species including Bacillus licheniformis, Bacillus sp KSM-P410 and Fusarium oxysporum. ${ }^{36}$ Regarding rhamnopolygalacturonases, it was stated that the enzymes are more stable and efficiently work at $\mathrm{pH} 4.0$ and a temperature of $50^{\circ} \mathrm{C} .^{41}$ 


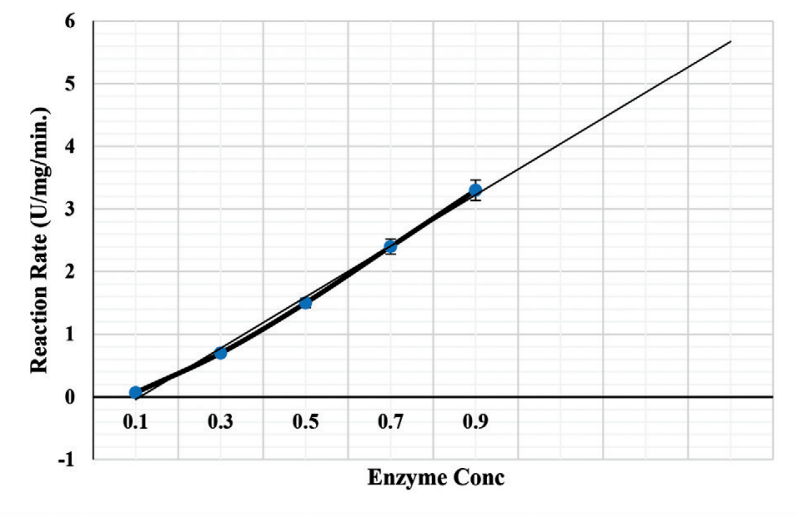

Fig. 11 Effect of different enzyme concentrations on pectiinase activity.

\section{Conclusion}

In the present study, the extracellular pectinase was produced by using Bacillus licheniformis FMB9 isolated from agricultural soil in Jeddah city at Kingdom of Saudi Arabia. The strain showed maximum pectinase activity after 72 of growth at $\mathrm{pH}$ 7.0 and $37^{\circ} \mathrm{C}$ hrs. After purification, pectinase was characterized and molecular weight was determined.

\begin{tabular}{cc}
\hline Table 5. Effect of metal ions on pectiinase activity \\
\hline Metal ion (1 mM) & Relative activity (\%) \\
\hline Control & 100 \\
$\mathrm{Na}^{+}$ & $90^{*}$ \\
$\mathrm{~K}^{+}$ & 115 \\
$\mathrm{Mg}^{2+}$ & 110 \\
$\mathrm{Fe}^{2+}$ & 97 \\
$\mathrm{Cu}^{2+}$ & 90 \\
$\mathrm{Ca}^{2+}$ & $104^{*}$ \\
$\mathrm{Zn}^{2+}$ & $110^{*}$ \\
$\mathrm{EDTA}$ & 70 \\
\hline
\end{tabular}

*Significant results using studied- $t$-test at $P<0.05$ compared with control without addition.

\section{Acknowledgment}

The authors are grateful to King Abdulaziz University, Department of Biology, College of Science for providing laboratory facilities.

\section{Conflict of Interest}

None.

\section{References}

1. Alkorta, I., Garbisu, C., Llama, M.J., Serra, J.L. (1998). Industrial applications of pectic enzymes: A review. Process Biochemistry journal, 33, 21-28.

2. Satapathy S, Rout JR, Kerry RG, Thatoi H, Sahoo S L. (2020). Biochemical Prospects of Various Microbial Pectinase and Pectin: An Approachable Concept in Pharmaceutical Bioprocessing. Frontiers in Nutrition 7: 1222-1229.

3. Kavuthodi B. and Sebastian D (2018). Review on Bacterial Production of Alkaline Pectinase with Special Emphasis on Bacillus Species. Bioscience Biotechnology Research Communications, 11: 18-30.

4. Rebello S., Anju M., Aneesh E. M., Sindhu, R., Binod, P. and Pandey, A. (2017). Recent advancements in the production and application of microbial pectinases: an overview. Reviews in environmental science and bio/ technology, 16(3):381-394.

5. Yadav S, Yadav P K, Yadav D and Yadav KDS (2009). Pectin lyase: a review. Process biochemistry, 44(1):1-10.

6. Govindaraji, P. K., \&Vuppu, S. (2020). Characterisation of pectin and optimization of pectinase enzyme from novel Streptomyces fumigatiscleroticus VIT-SP4 for drug delivery and concrete crack-healing applications: An eco-friendly approach. Saudi journal of biological sciences, 27(12), 3529-3540.

7. Hankin, L., Zucker, M. and Sands, D.C. (1999). Improved solid medium for the detection and enumeration of pectolytic bacteria. Journal of Applied Microbiology, 38: 205-209.

8. Vu NT, Quach T N, Dao X, Le H, Le C P, Nguyen L T, Le L, Hoang H, Chu H H, Phi Q. (2021). A genomic perspective on the potential of termite-associated Cellulosimicrobium cellulans MP1 as producer of plant biomass-acting enzymes and exopolysaccharides. PeerJ 9, pages e11839.

9. Pedrolli, D.B., Monteiro, A.C., Gomes, E., Carmona, E.C. (2009). Pectin and pectinases: Production, characterization and industrial application of microbial pectinolytic enzymes, The Open Biotechnology Journal, 3: 9-18.

10. Chudasama, K.S. and Thaker, V.S. (2012). Secretion of type II extracellular cell wall degrading enzymes from Pantoeaagglomeransphytopathogen., Asian Journal of Plant Science \& Research., 2(5):559-565.

11. Kumar DJM, Saranya GM, Suresh K, Priyadharshini DA., Rajakumar R, et al. (2012). Production and optimization of pectinase from Bacillus sp. MFW7 using cassava waste. Asian Journal of Plant Science \& Research, 3: 369-375

12. Bateman DF, Millar RL (1966). Pectic enzymes in tissue degradation. Ann. Rev. Phytopathol. 4: 119-146.

13. Juven BJ, Lindner P and Weisslowicz H (1985). Pectin degradation in plant by Leuconostoc mesenteroides. Journal of applied bacteriology, 58: 533.
14. Neves,M.A.D., Kimura, T., Shimizu,N., and Shiiba. K. (2006). Production of Alcohol by simultaneous saccharification and fermentation of low-grade wheat flour. The Brazilian Archives of Biology and Technology, 49: 481-490.

15. Janani, L.K., Kumar, G., BhaskaraRao, K.V. (2011). Production and Optimization of Pectinase from Bacillus sp. MFW7 using Cassava Waste. Asian Journal of Biochemical and Pharmaceutical Research, 2:329-336.

16. Mohandas, A., Raveendran, S., Parameswaran, B., Abraham, A., Athira, R. S., Kuruvilla Mathew, A and Pandey A. (2018). Production of pectinase from Bacillus sonorensis MPTD1. Food technology and biotechnology, 56(1), 110-116.

17. Miller, G.L. (1959). Use of dinitrosalicylic acid reagent for determination of reducing sugar. Analytical Chemistry, 31: 426-428.

18. Roy K., Dey S., Uddin M., Barua R and Hossain M. (2018). Extracellular pectinase from a novel bacterium Chryseobacteriumindologenes strain SD and its application in fruit juice clarification. Enzyme research.

19. Holt, J.G., Krieg, N.R., Sneath, P.H.A., Staley, J.T., William, S.T. (1994). Bergeys Manual of Determinative Bacteriology, nineth ed., Williams and Walkins, Baltimore, 787.

20. Chen, W., Kuo, T. (1993). Nucleic Acids Research Journal, 21: 2260.

21. Lowry OH, Rosgrough NJ,Farr AL, Randall R J (1951). Protein Measurement with the Folin Phenol Reagent. The Journal of Biological Chemistry, 193, $165-275$.

22. Laemmli UK (1970). Cleavage of the Structural Proteins During Assembly of the Head of Bacteriophage T4. Nature, 227, 680-685.

23. Namasivayam E, Ravindar JD, Mariappan KA, Kumar M. (2011). Production of extracellular pectinase by Bacillus cereus isolated from market solid waste. J Bioanal Biomed., 3: 070-075.

24. Vibha B. and Neelam G. (2010). Exploitation of microorganisms for screening of pectinase from environment. ${ }^{\text {th }}$ International Conference in food, USA.

25. Hirose, N., Kishida, M., Kawasaki,H, Sakai, T. (1999) Purification and Characterization of an Endo Polygalacturonase from a Mutant of Saccharomyces cerevisiae. Bioscience, Biotechnology, and Biochemistry. 63(6): 1100-1103.

26. Aaisha,G. and Barate, D. (2016). Isolation and Identification of Pectinolytic Bacteria from Soil Samples of Akola Region, India. International Journal of Current Microbiology and Applied Sciences, 5: 514-521.

27. Oumer, O. J., \& Abate, D. (2017). Characterization of pectinase from Bacillus subtilis strain Btk 27 and its potential application in removal of mucilage from coffee beans. Enzyme research, 2017.

28. Nawawi, M.H., Mohamad, R., Tahir, P.M. and W. Z. Saad, (2017). Extracellular Xylanopectinolytic Enzymes by Bacillus subtilis ADI1 from EFB's Compost, International Scholarly Research Notices, 7 
29. Guan, Y., Wang, Q., LV, C., Wang, D., \& Ye, X. (2021). Fermentation timedependent pectinase activity is associated with metabolomics variation in Bacillus licheniformis DY2. Process Biochemistry, 101, 147-155.

30. Takcı HAM and Turkmen FU (2016). Extracellular Pectinase Production and Purification from a Newly Isolated Bacillus subtilis Strain, International Journal of Food Properties, 19:11, 2443-2450.

31. Mukesh Kumar DJ, Saranya GM, Suresh K, Andal Priyadharshini D, Rajakumar R, Kalaichelvan PT (2012). Production and optimization of pectinase from Bacillus sp. MFW7 using Cassava Waste. Asian Journal of Plant Science and Research, 2, 369-375

32. Giacobbe S.; Pepe, O.; Ventorino, V.; Birolo, L.; Vinciguerra, R.; Faraco, V. 2014,Identification and Characterization of a Pectinolytic Enzyme from Paenibacillus Xylanolyticus. BioResources 9, 4873-4887.

33. Ashour SM, Kheiralla ZMH, Eldiwany Al, Maa ny DA (2014). Production, Purification and Characterization of Polysaccharide Lytic Enzymes of a Marine Isolate, Bacillus Cereus NRC -20 and Their Application in Biofil Removal. African Journal of Microbiology Research , 8, 2492-2504.

34. Arijit, D.; Sourav, B.; Naimisha, R.V.; Rajan, S.S. Improved Production and Purification of Pectinase from Streptomyces sp. GHBA10 Isolated from Valapattanam Mangrove Habitat, Kerala, India. International Research Journal of Biological Sciences 2013, 2, 16-22.
35. Kashyap, D.R.; Chandra, S.; Kaul, A.; Tewari, R. (2000). Production, Purification, and Characterization of Pectinase from a Bacillus sp. DT7. World Journal of Microbiology and Biotechnology, 16, 277-282.

36. Bhardwaj, V.; Garg, N. (2012). Production, Purification of Pectinase from Bacillus sp. MBRL576, Isolate and Its Application in Extraction of Juice. International Journal of Science and Research, 3, 648-652.

37. Barnby FM, Morpeth FF, Pyle DL (1990). Endopolygalacturonase production from Kluyveromyces marxianus. I. Resolution, purification and partial characterization of the enzyme. Enzyme Microb. Technol., 12:891-7.

38. Jayani RS, Saxena S, Gupta R. (2005). Microbial pectinolytic enzymes: a review. Process Biochem., 40:2931-44.

39. Shrestha S, Khatiwada J R, Zhang X, Chio C, Kognou A Chen, F, Han S, Chen X, Qin W. (2021). Screening and Molecular Identification of Novel Pectinolytic Bacteria from Forest Soil. Fermentation 7:1, pages 40.

40. John J, Surendranathan K.K., Smith M L., Rahman P K.S.M., Chellam PV. (2020). Advances in upstream and downstream strategies of pectinase bioprocessing: A review. International Journal of Biological Macromolecules, 162, pages 1086-1099.

41. Mutter M, Beldman G, Pitson SM, Schols HA, Voragen AGJ. (1998). Rhamnogalacturonan a-D-galactopyranosylurono-hydrolase. Plant Physiol. 117:153-63. 